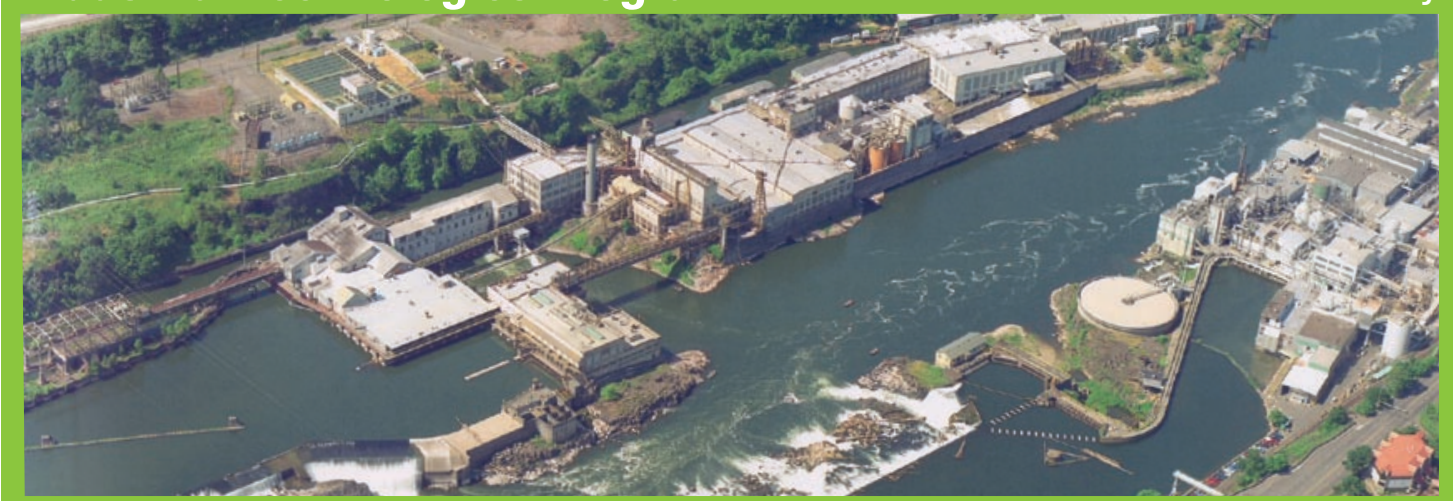

Steam is used to dry paper and power two papermaking machines at the West Linn Paper Company's mill in West Linn, Oregon, which produces nearly 700 tons daily of coated paper.

\title{
Longest-Serving Active Paper Mill in the Western United States Uncovers New Ways to Save Energy
}

Significant Natural Gas Savings Achieved Following Save Energy Now Assessment

\section{Benefits}

- Saves approximately $\$ 379,000$ annually

- Achieves annual natural gas savings of nearly 58,200 MMBtu

- Generates a simple payback of less than 6 months

\section{Key Findings}

- An independent, outside evaluation can validate energy savings measures.

- Although the West Linn paper mill had previously upgraded its boiler controls, the Save Energy Now assessment showed that these controls needed to be adjusted to improve energy efficiency.

- By connecting two separate steam headers, the West Linn mill significantly reduced its natural gas consumption.

- The assessment process taught plant employees how to analyze their steam processes and continue to identify energy savings opportunities in the future.

\section{Applications}

Steam systems are widespread in the pulp and paper industry and can account for a major part of a paper mill's energy consumption. Improving the efficiency of a paper mill's steam system can significantly reduce energy costs while maintaining reliability.

\section{Summary}

In March 2006, West Linn Paper Company received a Save Energy Now assessment from the U.S. Department of Energy (DOE) at the company's coated paper mill in West Linn, Oregon. While the mill was already taking measures to improve the efficiency of its steam system, DOE Energy Expert Bill Moir of Steam Engineering, Inc., conducted an assessment to help the plant identify additional opportunities with significant savings potential. Employees learned how to analyze the mill's energy consumption using DOE's suite of steam system software tools.

The assessment provided seven recommendations, including specific actions the plant could take immediately to implement the energy savings opportunities that had been considered previously but not yet completed, such as:

- Connecting two separate headers and installing a blow down heat recovery system.

- Adjusting the boiler combustion controls to lower the excess flue gas oxygen content.

- Performing a steam trap survey, repairing broken traps, and adding more insulation to the 200 psig header.

As a result of these efforts, the mill achieved annual natural gas savings of approximately 58,200 MMBtu.

With annual cost savings of $\$ 379,000$ and total implementation costs of $\$ 176,000$, the mill's simple payback was under 6 months.

\section{U.S. Department of Energy}




\section{Project Drivers}

The employees at the West Linn paper mill are motivated by the need to improve their company's competitiveness. In an effort to contain rising energy costs, mill personnel investigated and implemented several energy savings projects over the past decade. The Save Energy Now assessment helped consolidate various ideas and provided the economic and technical justification to implement additional energy efficiency projects. This enabled the mill to achieve significant energy savings in its steam system.

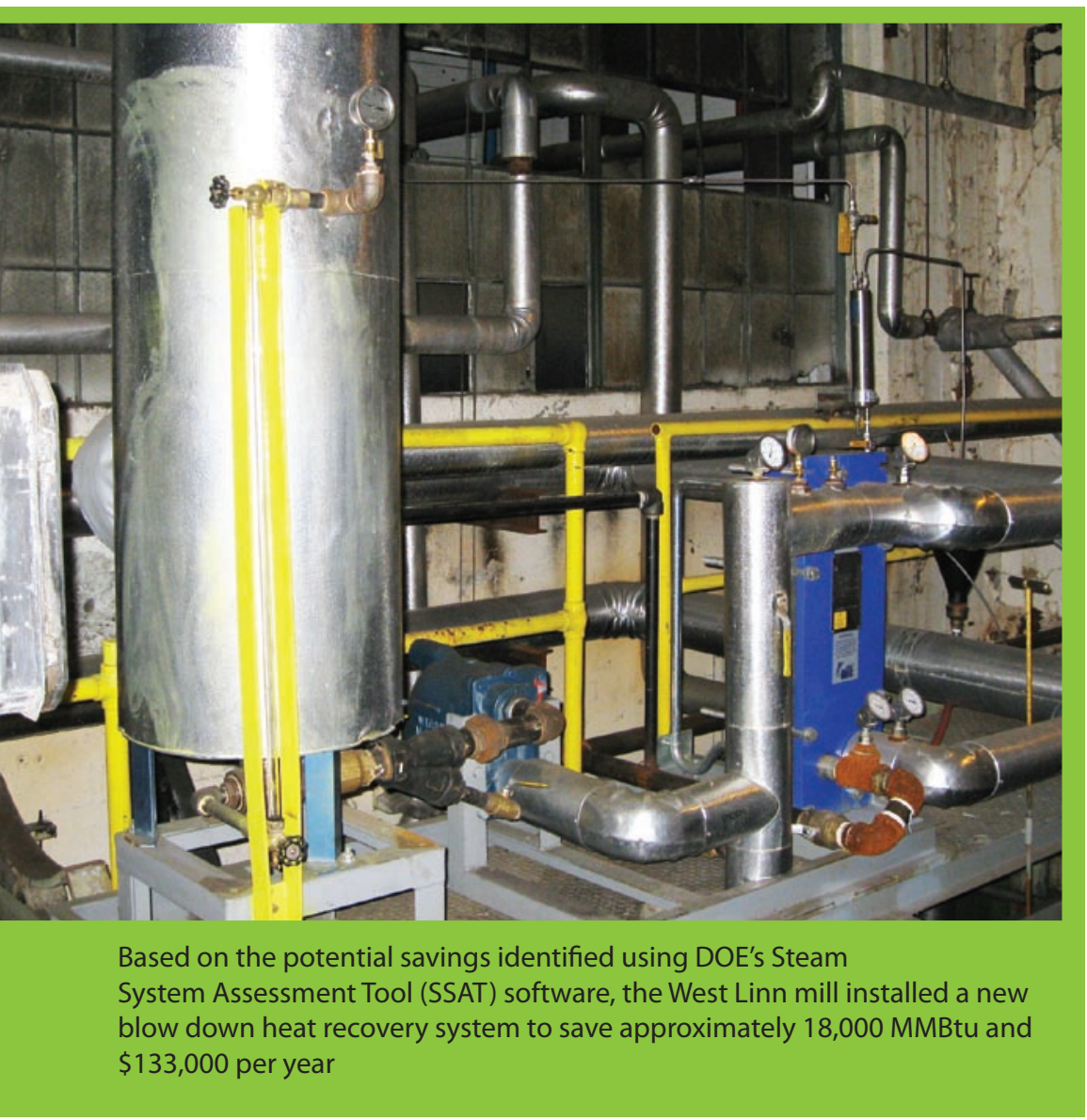

Founded in 1889 in West Linn, Oregon, the West Linn Paper Company is the oldest active paper mill and the largest manufacturer of coated free-sheet paper in the western United States. The mill's 250 employees produce close to 700 tons daily of coated paper under the Sonoma ${ }^{\circledR}$, Capistrano ${ }^{\circledR}$, and Nature $\mathrm{Web}^{\circledR}$ brand names. The company's paper products are sold throughout North America and are used for high-end advertising materials, magazines, catalogs, and book publishing.

The mill's steam system is served by three boilers, including two dual fuel (natural gas and No. 6 fuel oil) units and one natural gas-fired boiler. Steam is very important for the mill's production as it is used to dry paper and to power two back pressure turbines that drive the line shafts on two papermaking machines. At the time of the assessment, the steam system generated approximately $166,000 \mathrm{lbs} /$ hour at 200 psig.

While the mill does not have a formal energy management policy, energy efficiency is a strong priority. In the late 1990s the mill's steam load averaged nearly 200,000 lbs/hour. At a DOE-sponsored workshop several years earlier, mill personnel obtained $3 E$ Plus $^{\circledR}$, DOE's insulation assessment tool that enabled them to analyze their insulation levels. The mill began adding insulation to various parts of the steam distribution network and taking steps to improve efficiency, including performing regular steam trap surveys and maintenance. Plant personnel first began to realize the value of energy efficiency when they fixed the steam traps for the first time and the steam load was reduced by nearly $12,000 \mathrm{lbs}$. Since the mill began improving its steam system efficiency, energy use has declined from 7,500 to $5,200 \mathrm{lbs} /$ ton of paper and production has increased by $40 \%$.

\section{Assessment Overview}

The Save Energy Now assessment conducted at the West Linn mill was sponsored by the DOE Industrial Technologies Program (ITP), which provides Energy Experts to help industrial facilities evaluate and improve system efficiency. As a Qualified Specialist in the use of DOE's steam system assessment tool (SSAT) software, the Energy Expert formed an assessment team with mill employees and installed the SSAT on their computers. This enabled them to learn the software and review the data together to determine how they could make the mill's steam system more efficient. They also used SSAT to model the mill's steam system. 


\section{Assessment Recommendations}

After modeling the mill's steam system and evaluating the data, the assessment team identified seven energy savings opportunities and evaluated each one for technical and economic feasibility. They also compared the expected energy savings and associated payback periods in order to decide which were near-, medium-, or long-term opportunities.

\section{Near-term opportunity}

- Tune Boiler Controls - The mill had upgraded the boiler controls prior to the assessment. However, the team found that the average flue gas oxygen levels were above $4 \%$. By adjusting the oxygen trim controls to lower the oxygen levels, the assessment showed that boiler efficiency would improve. Annual energy and cost savings were estimated at $\$ 118,000$ and more than 15,500 MMBtu.

\section{- Improve Insulation; Survey and Repair Steam} Traps-Some areas of the 200 psig header were under insulated and the steam traps were due for the 6-month survey. Mill employees already familiar with DOE's 3E Plus software used the tool to estimate heat losses after the assessment, as well as energy savings from adding insulation and repairing malfunctioning steam traps.

\section{Medium-term opportunities}

- Extend 40 psig Header to Machine \#3-At the time of the assessment, the 40 psig steam header in the boiler room was unconnected to the 40 psig steam header that served paper machine \#3. In addition, the boiler room 40 psig steam header vented approximately 2,000 lbs of steam per hour. The assessment showed that if these headers were connected, the steam currently being vented could supply the paper machine. This would lower the mill's total steam load and yield natural gas savings of more than 23,000 MMBtu and cost savings of $\$ 175,000$ annually.

- Blow Down Heat Recovery-Before the assessment, the mill expected to install a blow down heat recovery system with a flash tank and a plate-andframe water-to-water heat exchanger. The team used the SSAT to analyze the effect this recovery system would have on the steam system's energy consumption and determined that it would save approximately $18,000 \mathrm{MMBtu}$ and $\$ 133,000$ per year in energy costs. This estimate was consistent with the mill's previous expectation.

- Remove Steam Heated Feed Water Heater-This water heater was installed to condense the 40 psig exhaust steam from the boiler room turbine drives. When the boiler room 40 psig header is extended to the 40 psig header on paper machine \#3, this water heater should be removed. Instead, a feed water economizer will be needed on boiler \#2 to allow the mill to shut off the feed water heater. This could lower the mill's steam load by 8,600 lbs/hour, yielding annual energy savings of approximately 97,000 MMBtu and \$721,000.

\section{Long-term opportunities}

- Use Alternate Fuel-At the time of the assessment, the mill depended primarily on natural gas that it fired in two boilers. The mill's use of No. 6 fuel oil was limited by air permit restrictions. The assessment modeled a fuel mix of $60 \%$ natural gas and $40 \%$ No. 6 fuel oil and concluded that this combination would be less expensive and more efficient than the current use of natural gas. The new fuel mix would increase average boiler efficiency yielding annual fuel savings of approximately 17,000 MMBtu and cost savings of $\$ 129,000$. However, West Linn staff realized that greater use of No. 6 oil would produce adverse environmental impacts. In addition, sustained use of No. 6 oil would be capital-intensive because soot blowers would need to be designed and installed.

\section{- Install a Feed Water Economizer on}

Boiler \#2 - The assessment found boiler \#2 had no heat traps and operated with a high flue gas temperature. An economizer installed to boost the temperature of the deaerated feed water before entering the boiler would reduce the flue gas temperature for the boiler. The efficiency of the system would be improved by enabling the boiler to use more heat, thereby reducing the amount of fuel it required. Estimated energy and cost savings were 27,000 MMBtu and \$223,000 per year.

If all the above recommendations were implemented, the total annual energy cost savings was estimated at approximately $\$ 1.5$ million.

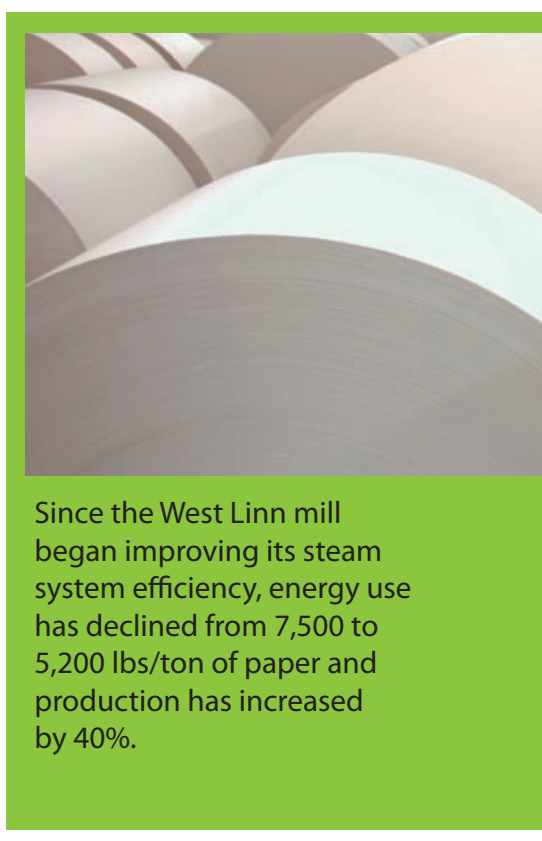

Since the West Linn mill began improving its steam system efficiency, energy use has declined from 7,500 to $5,200 \mathrm{lbs} /$ ton of paper and production has increased by $40 \%$

\author{
"The Save Energy Now Assessment was a great way to help \\ us quantify the opportunities we knew were out there and dis- \\ cover additional opportunities we hadn't seen before. It helped \\ us prioritize the work and sell it to mill management. Training \\ with the Steam System Assessment Tool program also gave \\ us a consistent method to evaluate new projects. It was time \\ well spent."
}

-Robert Hart, Engineering Manager, West Linn Paper Company 
